\title{
Evaluation of Dental Crowding in Mixes Dentition Comparison between two methods
}

\author{
DANA FESTILA ${ }^{1}$, MARIANA PACURAR ${ }^{2 *}$, LOREDANA GOLOVCENCU3*, DORIN NENOVICI ${ }^{4}$, ALEXANDRU ZALANA ${ }^{2}$, \\ MIRCEA GHERGIE ${ }^{1}$, ALEXANDRINA MUNTEAN ${ }^{5}$, MAGDALENA ENACHE ${ }^{6}$ \\ ${ }^{1}$ University of Medicine and Pharmacy luliu Hatieganu, Faculty of Dental Medicine, Orthodontic Department, 31Avram Iancu Str., \\ 400001, Cluj-Napoca, Romania \\ ${ }^{2}$ University of Medicine, Pharmacy, Science and Technology, Faculty of Dental Medicine, Orthodontic Department, 38 Gheorghe \\ Marinescu Str., Targu Mures, Romania \\ ${ }^{3}$ Grigore T. Popa University of Medicine and Pharmacy, Faculty of Medicine, Department of Psychiatry, 16 Universitatii Str., 700115, \\ Iasi, Romania \\ ${ }^{4}$ University of Medicine and Pharmacy Iuliu Hatieganu, Faculty of Dental Medicine, Surgical Department, 31Avram Iancu Str., \\ 400001, Cluj-Napoca, Romania \\ ${ }^{5}$ University of Medicine and Pharmacy luliu Hatieganu, Faculty of Dental Medicine, Pediatric Dentistry Department, 31Avram \\ Iancu Str., 400001, Cluj-Napoca, Romania \\ ${ }^{6}$ University of Medicine and Pharmacy Carol Davilla, Faculty of Dental Medicine, Orthodontic Department, 4-6 Eforiei Str., 050037 \\ ,Bucharest, Romania
}

\begin{abstract}
Assessment of dental crowding in mixed dentition from sixty-two study models, maxillary and mandibular, by two different methods was attempted. A single examiner compared the following methods: Nance that used brass wire for measuring the available space between the mesial surfaces of the first permanent molars and Lündstrom that includes the first permanentmolars and used digital calipers. The results showed Lündstrom method to be more reliable, reproducible and less time consuming.
\end{abstract}

Keywords: dental crowding, arch length, Nance method, Lündstrom method

Proper teeth alignment is a fundamental objective of orthodontic treatment. The exact evaluation of the dental crowding and the space required to solve it is essential for the correct diagnosis and treatment planning. An index of crowding is also useful from other perspectives: public health programs, epidemiological studies, and posttreatmentrecurrence monitoring [1-8]. Additionally, a valid and reproducible crow ding index would be useful for audit and research purposes. The degree of crowding in the dental arches is determined by the difference between the available space and the required space and can be expressed directly in millimeters or by an index [7]. Tooth - arch length discrepancy measurement is the most commonly used technique that evaluate the relationship between the available space of dental-alveolar arches and that needed for permanent teeth alignment, being used both in mixed and permanent dentition. The method was first described by Carey, which defines the perimeter as the linear dimension of the dental arch. [9]. It can be recorded on study models in a variety of ways: brass or multi-stranded wire measurement, straight-line segment measurement, indirect wire measurement techniques, arcograms, chain meters, and photographic. Recently, computer programs have been developed to be used in conjunction with model scanning and digital analysis. [1012]. The calculation of the tooth - arch length discrepancy has a prognostic value for the severity of a case and allows the determination of orthodontic treatment type: conservative or extraction. In order to correctly determine the orthodontic diagnosis and treatment plan, it is essential to choose an accurate method of assessing the dental crowding and space required for alignment. From the category of manual measurements, the most used are Nance and Lündstrom methods [4].

The Nance method measures the existing perimeter (space available) between the first right and left permanent molar mesial surfaces and the ideal perimeter (the required space), summing the mid-distal diameters of the permanent incisors and replacement teeth (canines and premolars).

Practically, for the measurement of the existing arch length (existing perimeter (PE) a brass wire, extended from left to right side between the first permanent molars, over the interdental contact points of the lateral teeth and the incisal edges of the anterior teeth considered as having a normal position on arch, is used. Next, the value in $\mathrm{mm}$ of the existing perimeter is determined by measuring the length of the wire with a ruler. In the case of dental malposition of the permanent teeth the wire will not follow these teeth; their mid-distal diameter can be measured and compared with the space between the proximal faces of the neighboring teeth without changing the thread path [13].

To calculate the ideal perimeter (PI), following formulas are used:

-Lower jaw: $\mathrm{PI}=$ si (sum of lower incisors) $+2 x+3.4$ (lower lee way space)

-Upper jaw: $\mathrm{PI}=\mathrm{SI}$ (sum of upper incisors) $+2 \mathrm{x}+1.8$ (upper lee wayspace) $\mathrm{Sl}$ is the sum of the four permanent incisors; $x$ is sum of the mid-distal diameters of canine and premolars measured on a one to one scale panoramic radiograph or taken from prediction charts. Determining the difference between the two perimeters results, in millimeters, in the deficit or surplus of arch space. In case of protrusion or frontal retrusion, the corrected shape of the arch (when measuring the existing perimeter) is taken into account [14]. The Lundstrom method involves the division of the dental arch into six segments, each containing tw 0 teeth, including the first permanent molar. The difference between the available space (recorded on the model using digital calipers) and the required space (maximum mid-distal teeth width) for each segment is

*email: Igolovcencu@yahoo.com, Phone:0749056796; marianapac@yahoo.com, Phone:0744952183 
made [15].The aim of our study was to compare these two techniques and to determine the most accurate, reliable, reproducible and rapid method to be used.

\section{Experimental part}

Material and method

The study was carried out on 60 patient's study casts. Including criteria were: age between 6 and 12 years old, mixed dentition, no previously orthodontic treatment, correctly molded casts with

completely erupted dental units, no fractures or injuries caused by carious lesions. The materials used were: soft brass wire $0.012 "$, scale, digital Vernier caliper (Mitutoyo Corporation, Japan) and a stopwatch. Tooth - arch length discrepancy was measured on every cast using two methods, Nance and Lündstrom consecutively, by a single examiner. Digital Vernier caliper was used in the Lündstrom method, digital Vernier caliper, brass wire and scale were used in the Nance method. The measurement time was recorded with the stopwatch for each individual method. For both methods the ideal perimeter was calculated using a prediction chart. The measurements were resumed in two other stages by the same examiner at two weeks' intervals. Mean values, standard deviation, random error using Dahlberg formula, systemic error using t-Student test and Pearson correlation coefficient were calculated for each method.

\section{Results and discussions}

Measuring arch length the mean values were higher when using the Lündstrom method in both arches, $95.4 \pm$ 4.3 compared with $78.2 \pm 3.5$ according to Nance method in the maxilla and $86.5 \pm 3.3$ compared with $69.1 \pm 3.6$ in the mandible. (table 1) The same results were obtained when the degree of dental crow ding was evaluated with a very significant difference in the mandible: $4.2 \pm 7.2$ according to Lundstrom compared with $1 \pm 4.5$ according to Nance method (table 1).

In terms of time spent per cast and per method to measure the dental arch length, Lündstrom method was more rapidly compared with Nance: 1.35 min versus 2.05 min.

\section{Random error}

By comparing the two methods, a lesser random error was obtained when using the digital caliper than the brass wire, both in upper and lower arch. In the upper arch, random error was of $0.59 \mathrm{~mm}$ and $0.86 \mathrm{~mm}$ when measuring the arch length and the dental crowding irrespectively, with the wire compared with $0.29 \mathrm{~mm}$ in both measurements using digital caliper. In the lower arch, random error was only $0.13 \mathrm{~mm}$ when Lündstrom method was used compared with $0.50 \mathrm{~mm}$ for the Nance (table 2).

Systematic error was significant with the Nance method: $0.60 \mathrm{~mm}$ in upper arch crowding and in both,

\begin{tabular}{|c|c|c|c|c|c|c|}
\hline & \multicolumn{3}{|c|}{ Arch length } & \multicolumn{3}{c|}{ Dental crowding } \\
\hline Method & $\begin{array}{c}\text { Minimum } \\
\text { value } \\
(\mathrm{mm})\end{array}$ & $\begin{array}{c}\text { Mean } \\
\text { value } \\
\text { Standard } \\
\text { deviation } \\
(\mathrm{mm})\end{array}$ & $\begin{array}{c}\text { Maximum } \\
\text { value } \\
(\mathrm{mm})\end{array}$ & $\begin{array}{c}\text { Minimum } \\
\text { value } \\
(\mathrm{mm})\end{array}$ & $\begin{array}{c}\text { Mean } \\
\text { value } \\
\text { Standard } \\
\text { deviation } \\
\text { (mm) }\end{array}$ & $\begin{array}{c}\text { Maximum } \\
\text { value } \\
(\mathrm{mm})\end{array}$ \\
\hline $\begin{array}{c}\text { Maxilla } \\
\text { (Nance) }\end{array}$ & 71 & $78.2 \pm 3.5$ & 82 & -8.2 & $2.5 \pm 6.0$ & 15.6 \\
\hline $\begin{array}{c}\text { Maxilla } \\
\text { (Lündstrom) }\end{array}$ & 83.02 & $95.4 \pm 4.3$ & 102.76 & -8.1 & $3.2 \pm 6.2$ & 24.1 \\
\hline $\begin{array}{c}\text { Mandible } \\
\text { (Nance) }\end{array}$ & 62 & $69.1 \pm 3.6$ & 78 & -10.2 & $1 \pm 4.5$ & 9.4 \\
\hline $\begin{array}{c}\text { Mandible } \\
\text { (Lündstrom) }\end{array}$ & 79.37 & $86.5 \pm 3.3$ & 93.25 & -3.6 & $4.2 \pm 7.2$ & 22.1 \\
\hline
\end{tabular}

\begin{tabular}{|c|c|c|c|c|}
\hline Method & Arch length $(\mathrm{mm})$ & $\begin{array}{c}\text { Dental crowding } \\
(\mathrm{mm})\end{array}$ & Arch length $(\mathrm{mm})$ & $\begin{array}{c}\text { Dental } \\
\text { crowding }(\mathrm{mm})\end{array}$ \\
\hline $\begin{array}{c}\text { Maxilla (Nance) } \\
\begin{array}{c}\text { Maxilla } \\
\text { (Lündstrom) }\end{array}\end{array}$ & 0.59 & 0.29 & -0.17 & $-0.60^{*}$ \\
\hline $\begin{array}{c}\text { Mandible } \\
\text { (Nance) }\end{array}$ & 0.50 & 0.50 & 0.15 & 0.17 \\
\hline $\begin{array}{c}\text { Mandible } \\
\text { (Lündstrom) }\end{array}$ & 0.13 & 0.13 & $1.18^{*}$ & $1.11^{*}$ \\
\hline
\end{tabular}

Table 1

MEAN VALUE AND STANDARD DEVIATION OF DENTAL ARCH PERIMETER AND CROWDING 
lower arch length ( $1.18 \mathrm{~mm}$ ) and degree of crowding ( 1.11 $\mathrm{mm}$ ) (table 2)

Pearson correlation coefficient was very high in both methods but especially in Lündstrom method. The difference was more significant in the upper arch when the degree of dental crowding was calculated: $r=0.99$ compared with $r=0.87$ with the Nance method (table 3). Limiting the study to completion by a single examiner significant errors can appear.

\begin{tabular}{|c|c|c|c}
\hline Method & $\begin{array}{c}\text { Arch } \\
\text { length }\end{array}$ & $\begin{array}{c}\text { Dental } \\
\text { crowding }\end{array}$ & \\
\hline $\begin{array}{c}\text { Maxilla } \\
\text { (Nance) }\end{array}$ & 0.92 & 0.87 & $\begin{array}{c}\text { Table 3 } \\
\text { PEARSON CORRELATION } \\
\text { COEFFICIENT (r) }\end{array}$ \\
\hdashline $\begin{array}{c}\text { Maxilla } \\
\text { (Lündstrom) }\end{array}$ & 0.98 & 0.99 & \\
\hline $\begin{array}{c}\text { Mandible } \\
\text { (Nance) }\end{array}$ & 0.96 & 0.94 & \\
\hdashline $\begin{array}{c}\text { Mandible } \\
\text { (Lündstrom) }\end{array}$ & 0.99 & 0.99 & \\
\hline
\end{tabular}

Random errors occur as a result of unpredictable factors that may be associated with the limitations of the work equipment, the technique used, or the practitioner's experience in reading the instrument results and affect each measurement differently. According to the Houston study, the main source of random error occurs because of the difficulty of identifying or defining reference points for measurements. When measurements are repeated, it is difficult to reposition the instruments exactly in the same position [16]. In our study, lower values of random error were obtained using the Lündstrom than using the Nance method. These results are supported by another comparative studies between the two methods did by Machado, Battagel, Bathia, Harisson et. al [17,18]. Opposite results were obtained by comparing the two methods with the electronic microscope, the wire method recording lower values of random errors [19]. The systematic errors that occurred during Lündstrom's study model analysis were insignificant in both the arch perimeter measurement and the dental crowding estimate. Instead, they were detected during Nance's analysis, making this method less reliable [17]. The current study showed a higher degree of reproducibility of the digital caliper method compared to the wire method following the three steps of resuming the measurements as confirmed by other studies, too [20-37].

\section{Conclusions}

No large differences were found between the two methods in terms of random errors. Instead, from the perspective of systemic errors, the Nance method is considered inappropriate for measuring available space and assessing dental crowding. The results reported a higher degree of reproducibility of the Lündstrom than the Nance method and a shorter completion.

\section{References}

1.HOWE, RP, MCNAMARA, J.A., O'CONNOR, K.A., An examination of dental crow ding and its relationship to tooth size and arch dimension, Am J Orthod., 83, no.5, 1983, p. 363.
2. WARREN, J., BISHARA, S., YONEZU, T., Tooth size-arch length relationships in the deciduous dentition: a comparison between contemporary and historical samples. Am J Orthod Dentofac Orthop., 123, no.6, 2003, p. 614.

3. HUNTER, WS., Application of analysis of crowding and spacing of the teeth, Dent Clin North Am., 22, 1978, p. 563. 4. JOHAL, A., BATTAGEL, J., Dental crowding: a comparison of three methods of assessment, Eur J Orthodont., 19, no. 5, 1997, p. 543. 5. AL-KHATEEB, S.N., ABU ALHAIJA, E.S., Tooth size discrepancies and arch parameters among different malocclusions in a Jordanian sample, Angle Orthod., 76, 2006, p.459.

6. MANJULA, M., RANI, S.T., DAVID, S.R., REDDY, E.R., SREELAKSHMI, N., RAJESH, A., Applicability of tooth size predictions in the mixed dentition space analysis in Nalgonda population, J NTR Univ Health Sci, 2, 2013, p. 269.

7. FARUQUIA, S., FIDAB, M., SHAIK, A., Comparison of tooth and arch dimensions in dental crowding and spacing, POJ , 4, no.2, 2012, p. 48. 8. WALLIS, C., MCNAMARA, C., CUNNINGHAM, S.J ., SHERRIFF, M., SANDY, J.R., IRELAND, A.J ., How good are we at estimating crowding and how does it affect our treatment decisions? Eur J Orthod, 36, no.4, 2014, p. 465.

9. CAREY, C.W., Linear arch dimensions and tooth size. Am J Orthod., 35, 1949, p.762.

10. BURSTONE, J., The uses of computers in orthodontic practice, Part2,J CO,13,1979,p.539.

11. KUMAR, P.M., KUMAR, P.N., SESHAM, V.M, Model Analysis on a Smartphone, JCO, XLVI, no. 6, 2012, p. 356.

12. GRUNHEID, T., PATEL, N., DE FELIPPE, N.L., WEY, A., GAILLARD, P.R., LARSON, B.E., Accuracy, reproducibility, and time efficiency of dental measurements using different technologies. Am J Orthod Dentofac Orthop,145, no.2 2014, p.157.

13. NANCE, H.N., Limitations of orthodontic treatment, Am J Orthod, 33, 1947, p.177.

14. VERNESCU LEHENI V., Anomalia dento-alveolara, Editura Medicala, Bucuresti, 1979, p. 60

15. LUNDSTROM, A., Introduction to Orthodontics, McGraw- Hill Book Company, Inc, New York, 1960, American J Orthod, 49, no. 6, 1963, p. 472

16. HOUSTON, W.J.B., The analysis of errors in orthodontic measurements,Am J Orthod, 83, no.5, 1983, p. 382. 17. MACHADO, L., VASCONCELLOS VILELLA, O., AGOSTINHO, L., Evaluation of two techniques to measure the available space in the mandibular dental arch using the method error, Revista Odonto Ciencia, 27, no. 3, 2012, p. 228.

18. BATTAGEL, M., Individualized catenary curves: their relationship to arch form and perimeter, Br J Orthod, 23, no.1, 1996, p. 21. 19. BATHIA, S., HARRISON, E., Operational Performance of the Travelling Microscope in the Measurement of Dental Casts, Br J Orthod, 14, 1987, p.147.

20. KEVIN, H., MOK, Y., Space analysis: a comparison between sonic digitization (DigiGraph Workstation) and the digital caliper. Eur J Orthod, 120, no.6, 1998, p. 653.

21. GUPTA, S., KAHLON, S.S., DHINGRA, P.S., KAUR, S., KAUR, H., DHALIWAL, B., A comparative evaluation of digital and manual method for dental cast analyses, Indian Journal of Comprehensive Dental Care, 7, no.1, 2017, p. 876.

22. SUJA, A., BABU, C., PRESANTH, S., Assessment of dental crowding, JMS, 4, no.1, 2014, p. 52.

23.NICULESCU,O., NICA,P., GURLUI,S.,et al., Experimental investigations of polymer plasma laser ablation, Mat.Plast., 46, no.3, 2009, pg.336-338

24.NASH,D.,RUOTOISTENMAKI, ., ARGENTIERI,A.et al.,Profil of the oral healhcare team in countries with emerging economies, Conference Global Congress on Dental Education location, Dublin,Ireland, European J ournal of Dental Education,12((1), 2008, pg.111-119 
25.J UMANCA D., GALUSCAN,A., PODARIU,A.C., et al., Anti-inflammatory action of toothpastes conaining betulin nanocapsules, Rev.Chim.(Bucharest), 65,no.12,2014,p.1473-1476

26. ANCUTA ,C., POMIRLEANU, C., IORDACHE,C., et al., Serum lipid profile in diffuse versus limited systemic sclerosis data from the SASS cohort, Rev.Chim.(Bucharest), 69, no.2, 2018, pg.403-406

27. GRIGORE, M., FURNICA, C., ESANU, I., et al., Pentalogy of Cantrell associated with unilateral anophthalmia .Case reportand literature review, Medicine, 97(31), 2018

28.IORDACHE ,C., GHIORGE,C.A., ANTOHE M.E., et al., Temporomandibular joint involvement in rheumatoid arthritis and ankylosing spondylitis:a cross-sectional study, 994),Romanian J ournal of Oral Rehabilitation 2017 ,pg.40-46

29.MURARIU,A., PRICOP M., BOBU,L., et al., Ethics dimensions in dentistry, Romanian Journal of Oral Rehabiliation,8(1), 2016,pg.65-71 30.POPA, C., STELEA, C.G., FILIOREANU, A.M., et al., PCR Analysis of the Herpesviruses presence in crevicular fluid in HIV-positive patients, Rev.Chim.(Bucharest), 68, no.11, 2017, p.2672-2675

31.FORNA AGOP, D., POPESCU,E., COSTAN V.V., et al.,Conventional maxillary reconstruction using service obturators, Romanian Journal of Oral rehabilitation,(8),3,2016, pg.32-39
32.DASCALU, C.G., CARAUSU, E.M., MANUC, D., Methods for Data Selection in Medical Databases: The Binary Logistic Regression Relations with the Calculated Risks, Proceedings of world academy of science, engineering and technology, VOL $28 \mathrm{Book}$ Series: Proceedings of World Academy of Science Engineering and Technology Volume: 28 Pages: 278-+ Published: 2008

33.BRANISTEANU,D.E.,IANOSI,S.L.,DIMITRIU,A., et al., Drug-induced Rowell syndrome, a rare and dufficult to manage disease:A case report, Experimental and therapeutic medicine,15(1), 2018,p.785

34.EARAR, K., ANTONIAC, V.I., BACIU, S., et al, Etching treatment effect on surface morphology of dental structures, Rev. Chim.(Bucharest), 68, no.11,2017, p.2700

35.BUDACU,C.C., CIORANU,S., IBRIC, V., CHISCOP, MI., et.al.,Glucocorticoids and postoperative disease in oral -maxillo-facial surgery, Rev. Chim.(Bucharest), 68, no.11, 2017, p.2716

36.MARTU,I., LUCHIAN,I., DIACONU-POPA, D. et.al., Clinical and technological particularities regarding unidental restoration using ceramic crwns with a zirconia infrastructure.a case report,,Romanian Journal of Oral Rehabilitation,9(1),2017, pg.27-31.

37.SCUTARIU,MM, CIURCANU,O.E., FORNA AGOP, D. Etal. , Importance of dental maxillofacial aesthetic in dental therapy, Medical-surgical journal, revista medico-chirurgicala, 120(4), 2016, p.926

Manuscript received: 14.09 .2018 